ISSN 0258-7122 (Print), 2408-8293 (Online)

Bangladesh J. Agril. Res. 43(2): 301-307, June 2018

\title{
EVALUATION OF PROMISING MAIZE HYBRIDS IN DIFFERENT REGIONS OF BANGLADESH
}

\author{
A. N. M. S. KARIM ${ }^{1}$, S. AHMED ${ }^{2}$, A. H. AKHI ${ }^{3}$ \\ M. Z. A. TALUKDER ${ }^{4}$ AND T. A. MUJAHIDI ${ }^{5}$
}

\begin{abstract}
Nine single cross promising maize hybrids and three check varieties (NK40, BHM9 and 900 MGold) were assessed for genotype environment interaction (GEI) and stability for the selection of promising one(s) in seven different locations of Bangladesh. The AMMI (additive main effects and multiplicative interaction) model was used to analyze the genotype-environment interaction over seven locations to select desired hybrid having higher yield and other potential attributes. Regarding genotypes $(G)$, significant variation was found in all the characters except yield while environment (E) was found significant for all the characters. The environment of Gazipur was poor; Jamalpur, Hathazari, Ishurdi, Rahmatpur, Burirhat, and Jessore were positive environments for tested maize hybrids. Considering the mean, bi and $S^{2}$ di for all the parameters, it was evident that all the genotypes showed different response of adaptability under different environmental conditions. Among the hybrids E12 (900MG), E7(CML502 × CML491), E1(BIL95 × BIL28), E10 $($ NK40) and E2 (BIL95 $\times$ BIL31) were exhibited high yielder.Considering bi 1(regression co-efficient), $\mathrm{S}^{2} \mathrm{di} \sim 0$ (deviation from regression)and mean versace IPCA1 (fig1)indicated that hybrids E7and E1showed the higher yield as well as stable across locations.
\end{abstract}

Keywords: combing ability, maize hybrids, stability, different environments

\section{Introduction}

Multi-environment yield trials are used commonly to release superior genotypes for target sites in plant breeding programs. Genotype Environment Interaction (GEI) is universal phenomenon when different genotypes are tested in a number of environments. The large GEI variation usually impairs the accuracy of yield estimation and reduces the relationship between genotypic and phenotypic values (Nachit et al., 1992). GEI due to different responses of genotypes in diverse environments makes choosing the superior genotypes difficult in plant breeding programs. Numerous methods for multi-environment trials data have been developed to expose patterns of $\mathrm{G} \times \mathrm{E}$ interaction (Yamada, 1962), joint regression (Finlay and Wilkinson, 1963; Eberhart and Russel, 1966) and currently AMMI (Gauch, 1992) and GGE biplot (genotype main effect plus genotype by environment interaction). AMMI model combines the analysis of

${ }^{1,3 \& 5}$ Scientific Officer, Plant Breeding Division, Bangladesh Agricultural Research Institute (BARI), Gazipur, ${ }^{2}$ Principal Scientific Officer, Plant Breeding Division, BARI, Gazipur, ${ }^{4}$ Senior Scientific Officer, Plant Breeding Division, BARI, Gazipur, Bangladesh. 
variance of genotypes and the environment main effects with principal component analysis of the GEI into a unified approach (Gauch and Zobel, 1996). Crossa et al. (1990) indicated that the AMMI model can be used to analyze the GEI and to identify the superior hybrid maize genotypes. Also, he pointed out that it can be used in the selection of the best test environments for hybrid maize genotype evaluation. Kaya et al. (2002) suggested that the interaction of the 20 genotypes with six environments was best predicted by the first two principal components of genotypes and environments. Also, they proposed that biplots generated using genotypic and environmental scores of the first two AMMI components can be used by breeders and have an overall picture of the behavior of the genotype, the environment and GEIs. More precise GEI estimates can be obtained with the AMMI model which makes to easier to interpret the results (Durate and Vencovsky, 1999).

Maize is one of the most important food grains in the world as well as in developing countries like Bangladesh. It is the highest yielding grain crop having various uses. A great combination of high market demand with relatively low production cost, ready market and high yield has generated great interest among the farmers in maize cultivation. Day by day it is gaining popularity in the country due to vast demand, particularly for poultry industry. In Bangladesh it is the third most important crop after rice and wheat and it accounts for $4.8 \%$ of the total cropped land area and $3.5 \%$ of the value of agricultural output (Ahmad et al., 2011). In 2015-16, maize was cultivated in 3.5 lac hectare of land in Bangladesh and production was 25 lac mtons (Bidan, 2016). The objective of this study was to use the AMMI analysis model to assess the stability of some maize hybrids and verify the influence of a sample of environments at different locations of Bangladesh (Gazipur, Jamalpur, Hathazari, Ishurdi, Rahmatpur, Burirhat, and Jessore) in the productive performance of these hybrids.

\section{Materials and Methods}

The experiment was conducted at seven locations namely Gazipur, Jamalpur, Hathazari, Ishurdi, Rahmatpur, Burirhat, and Jessore during rabi 2014-15. Nine hybrids and three check varieties were evaluated in this study. The experiment was laid out in Randomized Complete Block Design with 3 replications. Seeds of each entry were sown in two rows, $4 \mathrm{~m}$ long plots with $60 \mathrm{~cm}$ and $20 \mathrm{~cm}$ spacing between rows and hills, respectively. Seeds were sown at Gazipur on 14 December, Jamalpur on 27 November, Hathazari on 4 November, Ishuardi on 25 November, Rahmatpur on 24 November, Burirhat on 21 November and Jessore on 19 November. One healthy seedling per hill was kept after thinning. Fertilizers were applied @ 250, 55, 110 40, 5 and $1.5 \mathrm{~kg} / \mathrm{ha}$ of N, P, K, S, Zn and B respectively. Standard agronomic practices were followed(Quayyum, 1993) and plant protection measures were taken as required. Two border rows at both end of each replication were used for minimize the border effect. Data on days to pollen shedding, days to silking was recorded on whole plot basis. Ten randomly selected plants were used for recording observations on plant and ear height. All the plants in two rows were considered for plot yield and converted to t/ha. 
The analysis of variance (ANOVA) was used and the GE interaction was estimated by the AMMI model (Zobelet. al., 1988). In this procedure, the contribution of each genotype and each environment to the GE interaction is assessed by use of the biplot graph display in which yield means are plotted against the scores of the first principal component of the interaction (IPCA1). The computational program for AMMI analyses is supplied by Duarte and Vencovsky (1999).The stability parameters, regression coefficient (bi) and deviation from regression $\left(\mathrm{S}^{2} \mathrm{di}\right)$ were estimated according to Eberhart and Russel (1966). Significance of differences among bi value and unity was tested by t-test while between $S^{2}$ di and zero by F-test. All the data were processed and analyzed using Cropsatat 7.2 program.

\section{Results and Discussion}

Results of combined analysis of variance for five characters of twelve hybrids at seven environments are presented in Table 2. The mean sum of squares for the genotypes was highly significant for all the traits except yield which revealed the presence of genetic variability in the material under studied. Environments mean sum of squares were highly significant for all of the characters. The highly significant effects of environment indicate high differential genotypic response across the different environments. The variation in soil structure and moisture across the different environments were considered as a major underlying causal factor for the GXE interaction. Environment relative magnitude was much higher than genotypic effect, suggesting that performance of each genotype is influenced more by environmental factors.

Table 1.Climatic scenario of seven locations in Bangladesh

\begin{tabular}{l|l|l|l|l|l}
\hline \multirow{2}{*}{ Location } & \multicolumn{5}{c}{ Ecology } \\
\cline { 2 - 7 } & Latitude & Longitude & $\begin{array}{c}\text { Seasonal } \\
\text { rainfall } \\
(\mathrm{mm})\end{array}$ & $\begin{array}{c}\text { Average } \\
\text { annual } \\
\text { temp. }\left({ }^{\circ} \mathrm{C}\right)\end{array}$ & \multicolumn{1}{c}{ AEZ } \\
\hline Gazipur & $24^{\circ} \mathrm{N}$ & $90.43^{\circ} \mathrm{E}$ & $800-1200$ & 25.8 & 18 (Madhupur Tract) \\
Rangpur & $25.33^{\circ} \mathrm{N}$ & $87.1^{\circ} \mathrm{E}$ & 2169 & 24.9 & 2 (Tista Flood Plain) \\
Jamalpur & $24.56^{\circ} \mathrm{N}$ & $89.55^{\circ} \mathrm{E}$ & $1,113.65$ & 26.3 & 8 (Young Brahmaputra and \\
& & & & & Jamuna Floodplain) \\
Barisal & $22.79^{\circ} \mathrm{N}$ & $90.29^{\circ} \mathrm{E}$ & $1620-1900$ & 25.9 & 13 (Ganges Tidal Floodplain) \\
Jessore & $23.17^{\circ} \mathrm{N}$ & $89.20^{\circ} \mathrm{E}$ & $1460-1500$ & 25.7 & 11 (High Ganges \\
& & & & & RiverFloodplain) \\
Hathazari & $22.5^{\circ} \mathrm{N}$ & $91.80^{\circ} \mathrm{E}$ & 2200 & 25.8 & 29 (Northern \& Eastern Hills) \\
Ishurdi & $26.12^{\circ} \mathrm{N}$ & $89.06^{\circ} \mathrm{E}$ & 1603 & 26.1 & 7(Active \\
& & & & & Jamuna Floodplain) \\
\hline
\end{tabular}

AEZ (Agro-Ecological Zones) 
Table 2. Full joint analysis of variance including the partitioning of the $G \times E$ interaction of maize hybrids over 7 locations during 2014-15

\begin{tabular}{l|l|l|l|l|l|l}
\hline \multirow{2}{*}{ Source of variation } & df & \begin{tabular}{c} 
Days to \\
pollen \\
\cline { 3 - 7 }
\end{tabular} & $\begin{array}{c}\text { Dhedding } \\
\text { silking }\end{array}$ & $\begin{array}{c}\text { Plant } \\
\text { height } \\
(\mathrm{cm})\end{array}$ & $\begin{array}{c}\text { Ear height } \\
(\mathrm{cm})\end{array}$ & $\begin{array}{c}\text { Grain yield } \\
(\mathrm{t} / \mathrm{ha})\end{array}$ \\
\hline Genotypes (G) & 11 & $15.80^{* *}$ & $18.25^{* *}$ & $507.61^{* *}$ & $286.84^{* *}$ & 1.94 \\
Environment (E) & 6 & $306.12^{* *}$ & $260.81^{* *}$ & $3768.01^{* *}$ & $2134.69^{* *}$ & $43.84^{* *}$ \\
Interaction G x E & 66 & 4.89 & 5.04 & 85.98 & 47.40 & 0.81 \\
AMMI & 16 & $14.13^{* *}$ & $15.50^{* *}$ & $230.48^{* *}$ & $99.50^{* *}$ & 1.83 \\
Component 1 & & & & & & \\
AMMI & 14 & $4.24^{* *}$ & $3.08^{* *}$ & $75.55^{* *}$ & $44.60^{* *}$ & 0.78 \\
Component 2 & & & & & & \\
GxE (Linear) & 11 & 8.58 & 8.57 & 162.94 & 117.81 & 0.34 \\
\hline $\begin{array}{l}\text { Pool deviation } \\
\text { Pooled error }\end{array}$ & 55 & 4.15 & 4.34 & 70.59 & 33.32 & 0.91 \\
\hline
\end{tabular}

$* \mathrm{P}<0.05, * * \mathrm{P}<0.01$

Table 3. Stability analysis for yield and different traits on maize over 7 locations during 2014-15

\begin{tabular}{|c|c|c|c|c|c|c|c|c|c|c|c|}
\hline \multirow{3}{*}{ Entry no. } & \multicolumn{11}{|c|}{ Days to pollen shedding } \\
\hline & \multicolumn{7}{|c|}{ Location } & \multirow{2}{*}{ Mean } & \multirow{2}{*}{$\mathrm{Pi}$} & \multirow{2}{*}{ bi } & \multirow{2}{*}{$\mathrm{S}^{2} \mathrm{di}$} \\
\hline & Gaz & Jam & Hat & Ish & Rah & Bur & Jes & & & & \\
\hline E1 & 97.33 & 93.33 & 88.00 & 101.30 & 88.33 & 98.33 & 100 & 95.24 & -0.03 & 0.98 & 5.75 \\
\hline E2 & 96.33 & 93.33 & 90.33 & 100.30 & 84.67 & 96.67 & 98.33 & 94.29 & -0.98 & 1.03 & 1.87 \\
\hline E3 & 91.33 & 91.00 & 93.00 & 96.00 & 85.33 & 96.33 & 96.0 & 92.71 & -2.55 & 0.64 & 6.03 \\
\hline E4 & 100.70 & 92.33 & 87.00 & 99.67 & 86.67 & 98.67 & 97.33 & 94.62 & -0.65 & 1.11 & 4.28 \\
\hline E5 & 101.30 & 95.33 & 90.67 & 101.70 & 87.33 & 100.00 & 100.0 & 96.62 & 1.34 & 1.10 & 1.22 \\
\hline E6 & 98.33 & 91.00 & 92.67 & 96.00 & 85.00 & 95.00 & 96.67 & 93.52 & -1.74 & 0.83 & 2.74 \\
\hline E7 & 103.70 & 95.67 & 90.67 & 103.70 & 85.33 & 101.30 & 97.67 & 96.86 & 1.48 & $1.33^{*}$ & 2.51 \\
\hline E8 & 104.00 & 96.33 & 88.00 & 104.30 & 87.00 & 102.70 & 98.33 & 97.24 & 1.96 & 1.35 & 7.00 \\
\hline E9 & 102.70 & 95.0 & 94.00 & 100.70 & 86.67 & 99.00 & 98.67 & 96.67 & 1.39 & 1.03 & 1.46 \\
\hline $\begin{array}{l}\text { E10 } \\
\text { (NK40) }\end{array}$ & 96.00 & 90.33 & 97.33 & 97.00 & 86.33 & 95.67 & 95.67 & 94.05 & -1.22 & 0.62 & 8.25 \\
\hline $\begin{array}{l}\text { E11 } \\
\text { (BHM9) }\end{array}$ & 97.33 & 93.33 & 95.67 & 99.00 & 85.67 & 97.33 & 95.00 & 94.76 & -0.50 & 0.79 & 4.13 \\
\hline $\begin{array}{l}\text { E12 } \\
\text { (900MG) }\end{array}$ & 101.70 & 94.0 & 93.67 & 102.30 & 86.33 & 100.00 & 98.67 & 96.67 & 1.39 & 1.12 & 0.44 \\
\hline Mean & 99.22 & 93.42 & 91.75 & 100.2 & 86.22 & 97.69 & 98.42 & - & - & - & - \\
\hline $\begin{array}{l}\text { E. } \\
\text { Index(Ij) }\end{array}$ & 3.95 & -1.85 & -3.52 & 4.89 & -9.04 & 2.42 & 3.14 & - & - & - & - \\
\hline $\begin{array}{l}\text { LSD } \\
(0.05)\end{array}$ & 1.65 & 1.40 & 1.42 & 1.31 & 4.06 & 0.88 & 1.84 & - & - & - & - \\
\hline
\end{tabular}

$\mathrm{Pi}=$ Phenotypic Indices, bi= regreaaion co-efficient and $\mathrm{S}^{2} \mathrm{di}=$ deviation from regression E1= BIL95 X BIL28, E2= BIL95 X BIL31, E3= BIL95 X BIL79, E4= CL02720 X CLQRCYQ17, E5= CML451 X CL02450, E6= CLQRCYQ59 X CML161, E7= CML502 X CML491, E8= CLQRCWQ24 X CML491, E9= CLQRCWQ10 X CML491, E10 $=$ NK40, E11= BHM9, E12=900 MGold 
Table 2.Cont'd.

\begin{tabular}{|c|c|c|c|c|c|c|c|c|c|c|c|}
\hline \multirow{3}{*}{ Entry } & \multicolumn{11}{|c|}{ Days to silking } \\
\hline & \multicolumn{7}{|c|}{ Location } & \multirow{2}{*}{$\begin{array}{c}\text { Overall } \\
\text { mean }\end{array}$} & \multirow{2}{*}{$\mathrm{Pi}$} & \multirow{2}{*}{ bi } & \multirow{2}{*}{$\mathrm{S}^{2} \mathrm{di}$} \\
\hline & Gaz & Jam & Hat & Ish & Rah & Bur & Jes & & & & \\
\hline E1 & 99.33 & 98.0 & 91.67 & 105.0 & 91.33 & 103.0 & 100.0 & 98.33 & 0.38 & 1.02 & 1.67 \\
\hline E2 & 98.33 & 97.33 & 93.67 & 103.7 & 87.67 & 101.3 & 97.33 & 97.05 & 0.90 & 1.08 & 2.05 \\
\hline E3 & 96.0 & 94.0 & 96.0 & 97.33 & 88.0 & 99.67 & 97.67 & 95.52 & -2.42 & 0.69 & 4.17 \\
\hline E4 & 102.3 & 96.0 & 91.33 & 102.3 & 90.0 & 101.0 & 100.0 & 97.57 & -0.37 & 1.06 & 3.05 \\
\hline E5 & 102.7 & 99.33 & 93.67 & 105.0 & 90.33 & 103.0 & 101.3 & 99.33 & 1.38 & 1.13 & 1.19 \\
\hline E6 & 99.33 & 93.67 & 95.0 & 97.0 & 88.33 & 99.67 & 95.33 & 95.48 & -2.47 & 0.74 & 3.44 \\
\hline E7 & 105.7 & 101.0 & 92.67 & 106.3 & 88.33 & 101.0 & 102.3 & 99.62 & 1.67 & 1.37 & 4.67 \\
\hline E8 & 105.3 & 100.3 & 90.67 & 107.7 & 89.67 & 101.7 & 103.0 & 99.76 & 1.81 & 1.39 & 7.73 \\
\hline E9 & 104.0 & 99.33 & 98.0 & 103.7 & 89.67 & 101.7 & 99.33 & 99.38 & 1.43 & 1.00 & 1.89 \\
\hline E10(NK40) & 98.0 & 93.33 & 100.3 & 98.0 & 89.0 & 100.0 & 96.33 & 96.43 & -1.52 & 0.59 & 10.3 \\
\hline E11(BHM9) & 99.0 & 98.0 & 98.0 & 100.3 & 88.67 & 98.67 & 98.33 & 97.29 & -0.66 & 0.75 & 3.27 \\
\hline $\begin{array}{l}\text { E12 } \\
\text { (900MG) }\end{array}$ & 103.3 & 99.0 & 96.67 & 105.3 & 89.33 & 101.7 & 102.0 & 99.62 & 1.67 & 1.13 & 0.66 \\
\hline Mean & 101.1 & 97.44 & 94.81 & 102.6 & 89.19 & 101 & 99.42 & - & - & - & - \\
\hline E. Inde & 3.16 & -0.50 & -3.14 & 4.69 & -8.75 & 3.07 & 1.46 & - & - & - & - \\
\hline $\operatorname{LSD}(0.05)$ & 1.4 .5 & 1.46 & 1.19 & 2.17 & 3.73 & 1.20 & 1.58 & 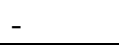 & - & - & - \\
\hline
\end{tabular}

Table 2.Cont'd.

\begin{tabular}{|c|c|c|c|c|c|c|c|c|c|c|c|}
\hline \multirow{3}{*}{ Entry } & \multicolumn{11}{|c|}{ Grain yield (t/ha) } \\
\hline & \multicolumn{7}{|c|}{ Location } & \multirow{2}{*}{$\begin{array}{c}\text { Overall } \\
\text { mean }\end{array}$} & \multirow{2}{*}{$\mathrm{Pi}$} & \multirow{2}{*}{ bi } & \multirow{2}{*}{$\mathrm{S}^{2} \mathrm{di}$} \\
\hline & $\mathrm{Gaz}$ & Jam & Hat & Ish & Rah & Bur & Jes & & & & \\
\hline E1 & 8.15 & 12.24 & 13.25 & 11.58 & 12.93 & 13.13 & 12.45 & 11.96 & 0.40 & 0.89 & 0.17 \\
\hline $\mathrm{E} 2$ & 7.94 & 10.88 & 13.98 & 10.56 & 12.66 & 12.99 & 12.24 & 11.60 & 0.08 & 0.99 & 1.06 \\
\hline E3 & 7.93 & 10.72 & 13.84 & 10.03 & 12.36 & 12.38 & 11.95 & 11.32 & -0.24 & 0.92 & 1.09 \\
\hline E4 & 7.24 & 11.95 & 13.91 & 11.17 & 12.65 & 10.66 & 10.38 & 11.14 & -0.41 & 0.94 & 1.01 \\
\hline E5 & 6.75 & 12.23 & 12.57 & 12.07 & 12.46 & 12.2 & 11.08 & 11.34 & -0.22 & 1.15 & 0.17 \\
\hline E6 & 5.99 & 10.67 & 13.96 & 10.79 & 12.02 & 10.64 & 9.65 & 10.53 & -1.02 & 1.20 & 1.12 \\
\hline E7 & 7.59 & 12.9 & 12.63 & 12.86 & 13.07 & 13.96 & 12.56 & 12.22 & 0.66 & 1.05 & 0.63 \\
\hline E8 & 7.50 & 13.19 & 11.59 & 11.85 & 12.46 & 11.34 & 11.13 & 11.29 & -0.26 & 0.88 & 1.01 \\
\hline E9 & 7.14 & 13.27 & 10.7 & 12.51 & 12.35 & 12.77 & 11.81 & 11.51 & -0.5 & 0.86 & 1.65 \\
\hline E10(NK40) & 7.72 & 11.49 & 13.95 & 11.46 & 13.03 & 12.98 & 11.98 & 11.80 & 0.33 & 0.97 & 0.62 \\
\hline E11(BHM9) & 7.33 & 12.75 & 11.43 & 11.86 & 12.33 & 12.3 & 11.62 & 11.37 & -0.18 & 0.89 & 1.02 \\
\hline E12(900MG) & 7.27 & 12.56 & 13.65 & 13.34 & 13.36 & 13.85 & 12.64 & 12.50 & 0.93 & 1.20 & 0.51 \\
\hline Mean & 7.38 & 12.07 & 13.25 & 11.67 & 12.64 & 12.50 & 11.62 & - & - & - & - \\
\hline E. Index $(\mathrm{Ij})$ & 4.17 & 0.51 & 1.46 & 0.11 & 1.07 & 0.94 & 0.06 & - & - & - & - \\
\hline $\operatorname{LSD}(0.05)$ & 1.09 & 1.55 & 1.95 & 1.53 & 2.31 & 1.46 & 1.65 & - & - & - & - \\
\hline
\end{tabular}

The AMMI biplot provide a visual expression of the relationship between the first interaction principal component axis (AMMI component 1) and mean of genotypes and environment (Fig. 1) as well as relationship of IPCA1 and IPCA 2. From the figure 1 it was observed that hybrids E12 (900MG), E7, E1, E10 (NK40) and E2 were highest yielder but among them hybrids E12 (900MG), E7, 
E1 and E10 (NK40) were more stable because they have smaller IPCA1 score which is near about zero.

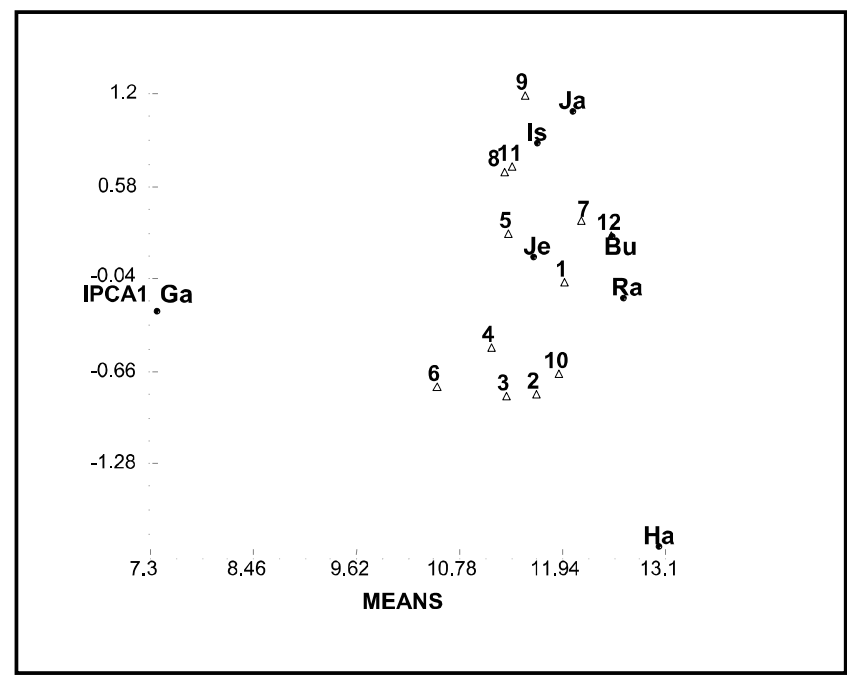

Fig.1. Biplot of the first AMMI interaction (IPCA1) score ( $\mathrm{Y}$-axis) plotted against mean yield (X-Axis) of twelve maize hybrids and seven environments.

Since IPCA2, scores also play a significant role in explaining the GEI; the IPCA1 scores were plotted against the IPCA2 score for further explanation of adaptation (Fig 2). The hybrids E4, E6, E8 and E9 were unstable due to their dispersed position. E1, E5 and E7 appeared to be more stable when plotting the IPCA1 and IPCA2 scores.

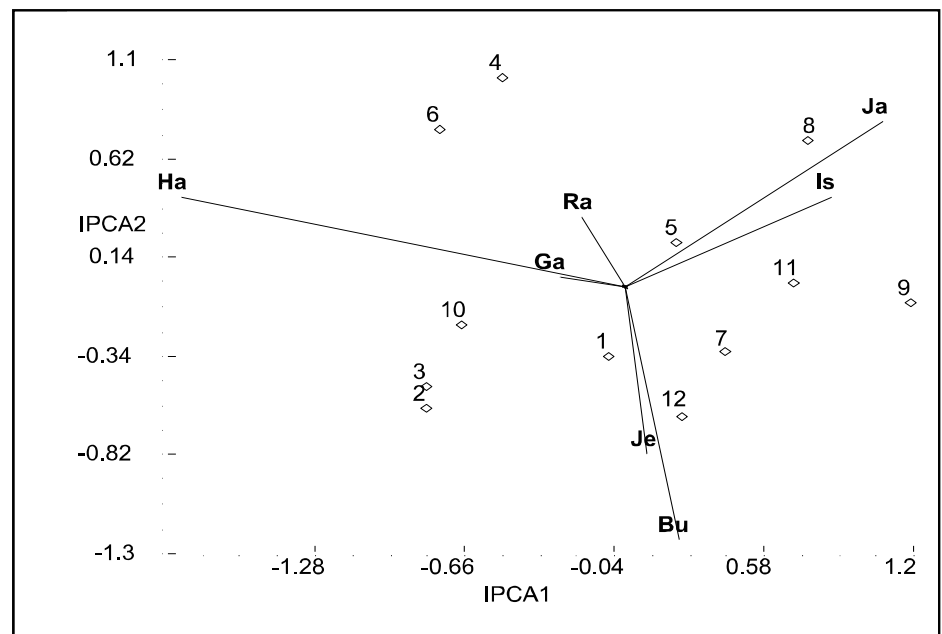

Fig.2 Biplot of the first AMMI interaction (IPCA2) score ( $Y$-axis) plotted against AMMI interaction (IPCA1) (X-Axis) of twelve maize hybrids and seven environments. 


\section{Conclusion}

Considering the yield potentially and stability parameters, two tested hybrids viz. E7 (CML502 × CML491) and E1 (BIL95 × BIL28) genotypes showed the highest yield as well as stable for over all environments and need to be further evaluated in large plots before release as commercial hybrids across ecological zones in Bangladesh.

\section{References}

Ahmad. S.Q., S. Khan, M. Ghaffar and P. Ahmad. 2011. Genetic diversity analysis for yield and other parameters in maize (Zea mays L.) genotype.Asian J. Agril. Sci. 3(5): 385-388.

Bidan, B. 2016.Agriculture Market information system in Bangladesh.Thimpu, Bhutan. Pp. 15-19.

Crossa, J. 1990. Statistical analysis of multilocation trails.Advances in Agronomy. 44: 55-85.

Duarte, J.B. and R. Vencovsky. 1999. Interação Genótipos x Ambientes: Uma introdução à análise .AMMI. Funpec, Ribeirão Preto, 60p. (sériemonografias, 9).

Eberhart, S.A. and W.A. Russel. 1966. Stability parameters for comparing varieties. Crop Sci. 6: 36-40.

Finlay, K.W. and G.N. Wilkinson. 1963. The analysis of adaptation in a plant breeding programme. Australian J. Agri. Res. 14: 742-754.

Gauch, H.G. 1992. Statistical analysis of regional yield trials: AMMI analysis of factorial designs. Elsevier, Amsterdam. P. 278.

Gauch, H.G. and , R.W. Zobel1996. AMMI analysis of yield trials. In: Genotype by Environment Interaction (Kang, M.S., Gauch, H.G., ed.). CRC Press, Boca Raton, FL. P. 85122.

Kaya, Y., Palta, C. and S. Taner. 2002. Additive main effects and multiplicative interactions analysis of yield performance in bread wheat genotypes a cross environments. Turkey J. Agric. For. 26: 275-279.

Nachit, M.N., M.E. Sorrells, R.W. Zobel, H.G. Gauch, R.A. Fischer and W.R. Coffman. 1992.Association of environmental variables with sites'mean grain yield and components of genotype environment interaction in durum wheat. J. Genet. Breed. 46: 369-372.

Quayyum, M.A. 1993. Bhuttar Chash Padhati. In: BhuttarUtpadan O babahar eds. M.K. Chowdhury and M.A. Islam. Bangladesh Agricultural Research Institute. pp 43-48.

Yamada, Y. 1962. GEI and genetic correlation of the same trait under different environments. Japan J. Genet. 37:498-509.

Zobel, R.W., A.J. Wright and H.G. Gauch Jr. 1988.Statistical analysis of a yield trial.J. Agron. 80: 388-393. 
